\title{
Comprehensive and Technical Efficiency of Insurance and Takaful Companies in Pakistan
}

\author{
Adnan Malik, Zahoor Khan, Sami Ullah Khan, Malik Muhammad ${ }^{3}$ \\ ${ }^{1,2}$ Institute of Management Sciences Peshawar, ${ }^{3}$ University of Swabi, ${ }^{4}$ IIU Islamabad
}

\section{Abstract}

Insurance and Takaful companies, both, are business organizations existing for the motive of profit. Large capital is required by the shareholders to establish a company; therefore, the company is expected to earn sufficient profit to meet the expectations of the shareholders. Moreover, a company also has its responsibilities towards its customers in terms of quality service. Shareholders are more concerned with their profit and customers regarding the services. Companies pay claims when the covered persons suffer a loss which can be the death of the family's only bread earner, factory on fire, theft of business goods etc. Therefore, efficient financial performance of insurance and Takaful companies is important to fulfil the requirements of both: shareholders and clients. This study investigates financial efficiency of insurance and Takaful companies via Data Envelopment Analysis during the period 2011 to 2015. We have taken six general (non - life ) insurance \& Takaful companies operating in Pakistan with input factors labor cost, assets and output factors premium / contribution received and percentage of claims paid. Results show that insurance and takaful companies are more than $80 \%$ efficient in their operations. For further increasing their efficiencies, they need to reduce their input by less than $20 \%$ to have same level of output. Comparing efficiencies of insurance and takaful companies, insurance companies are more efficient in terms of pure technical \& super efficiency while takaful companies have higher scale efficiency than insurance companies, though the difference in most of the cases is less than $2 \%$. Both types of companies need to improve their efficiencies by decreasing their assets input and labor cost while retaining the same output level of premiums and claims.

Keywords: General insurance, Data Envelopment Analysis (DEA); Malmquist index, Takaful, Scale and technical efficiency

\section{Introduction}

Use of efficiency measurement is increasing in the financial sector especially in

Corresponding Author: Adnan Malik, email: adnan.malik@imsciences.edu.pk 
the growing insurance and takaful industry. Cummins (2000) studied efficiency of 08 insurance companies. Antonio \& Akbar (2000) conducted a study on cost efficiency of insurance and takaful companies of Malaysia. Eling \& Luhnen (2010) studied 6462 life and general insurance companies based in 36 countries. Efficiency comparison of companies operating in different countries gives useful insights though these comparisons are confined to certain countries. Mostly, the studies focused on US, Japan, OECD and Switzerland (Weiss, 1991, 2000; Donni \& Fecher, 1997; Diacon et al, 2002).

Insurance companies are established with huge capital. Shareholders of a company make this investment for a good return and it is always a strategic investment which generates the benefit in long term. Big cash inflows of the company are premium earned and investment income when the collected premium is invested. Outflows include claim payments and administrative expenses. A company can be efficient only if it earns more profit when it receives more premium and investment income and pays less claims and incurs less administrative expenses.

Insurance and Takaful companies serve the society by compensating a customer if any of the defined losses occurs. The defined loss can be a theft of car, death of a client, destruction of factory due to earthquake. Such compensation enables a business to keep it continue ensuring no loss of jobs, goods and services. Therefore, it is important to check whether insurance or Takaful companies are efficient in terms of honoring their promises in the form of paying claims on timely basis.

In Pakistan, insurance growth in 2016 was recorded as $13 \%$ and premium collection was around Rs. 265 billion (Milliman, 2016). In year 2018, insurance and takaful companies of Pakistan received Rs. 308 billion which is around $0.89 \%$ of GDP (Insurance Association of Pakistan, 2019). Insurance sector paid tax of Rs. 5 billion in year 2015 (Hanif \& Iqbal, 2017).

In Pakistan, first Takaful company was established in 2006 under Takaful rules 2005. Presently, five full-fledged Takaful companies and more than 15 insurance companies providing takaful services are working in Pakistan (SECP, 2018). More than ten years have passed since the establishment of takaful companies in Pakistan; therefore, it is pertinent to compare the efficiency of takaful and insurance companies. Since lesser studies are conducted on comparing efficiencies of general insurance and takaful having similar size and nearby year of establishments; therefore, this study aims to compare efficiencies of 05 general insurance and takaful companies. Moreover, this study also contributes in the literature on the use of data envelopment analysis in insurance and 
takaful companies. For better and meaningful findings, comparison is made between general insurance and takaful companies having almost similar sizes and dates of incorporations.

Moreover, the present study aims to analyses the competitiveness of insurance and takaful companies, the most important elements of financial industry, and aims to suggest ways for improving their efficiencies. It will provide a comparison to the shareholders of the companies about the profit they earn on their investment with respect to earning of their competitors. They may take corrective measures if they are less efficient than their competitors. Regulators may constitute such laws which promote efficiency of the companies.

Introduction section will be followed by section 2 giving an over view of previous studies. Framework, variables, methodology and results are mentioned in section 03. Section 04 discusses the results with respect to the financial rating of the companies for that period. Section 05 discuss es the Malmquist index (mi) of insurance and takaful companies. Section 06 has a discussion on results, methodological contribution in 6 and conclusion in section 8 .

\section{Literature review}

\subsection{Insurance}

'Insurance is a mechanism in which a client transfers a financial risk to an entity that provides compensation, if an insured event occurs" (Malik \& Ullah, p.16, 2016). "Insurance involves transfer of potential losses to an insurance pool" (Dorfman, 1998, p. 3)

Oxford dictionary defines insurance as An arrangement by which a company or the state undertakes to provide a guarantee of compensation for specified loss, damage, illness, or death in return for payment of a specified premium". Insurance can be divided into two broad classes: Life insurance and non - life (General insurance). Life insurance coverage provides compensation when the customer dies while non -life coverage includes insurance of vehicles, goods, buildings etc. History of life insurance is very old and has different claims about its commencement. Some claim that general insurance started in $11^{\text {th }}$ century while the life insurance started from Italy in sixteenth century (Borscheid \& Haueter, 2012; Mace, 2016). In Pakistan, insurance/Takaful sector is comprised of around 30 general (Non - Life) insurance and 03 general Takaful (Islamic insurance) companies while life insurance companies are seven and family (Life) takaful companies are two (Insurance Association of Pakistan, 2019). 


\subsection{Takaful}

Takaful is defined as a system in which a common fund is created for compensating the fund members when they face a defined loss. It is based on principles of brotherhood, solidarity and mutual assistance with each other (Gonulal, 2012; Zainuddin \& Noh, 2013). First Takaful company was established in 1979 in Sudan (Billah, 2007). In Malaysia, first Takaful company was established in 1985 and today Malaysia leads the global Takaful market (Redzuan \& Aidid, 2009). In Pakistan, first general Takaful company was established in 2006 and life (family) Takaful company in 2008. Presently, two general and two-family Takaful companies are operating in Pakistan. One of the general Takaful companies' operations stands closed leaving only two general Takaful companies in Pakistan.

Studies have been carried out for measuring efficiency of insurance companies by using parametric and non-parametric approaches. These studies are conducted in developed and developing countries but very few researchers have tried to measure efficiency of Takaful companies. Some of these studies were conducted by Diacon (2002), Cummins and Misas (2001) however, Fukuyama (1997) studied the efficiency of Japanese insurance industry. Barros et al (2008) studied the Nigerian insurance industry using DEA from 1994 to 2005 and the findings revealed that technical efficiency of these firms is decreasing.

Khan and Noreen (2014) studied 12 conventional insurance companies including ten general and two life insurance companies and five Islamic insurance companies (three general and two-family Takaful) of Pakistan using data from 2006-2010. Input variables namely Labor, Capital and business services and output variable premium income were taken to measure the efficiency. They used data envelopment approach. The empirical results of cost efficiency indicate that Takaful companies are more efficient than conventional counterparts due to high allocative efficiency leading to the conclusion that their choice of inputs is optimal. Ismail and Bacha (2011) conducted a study on eighteen companies including four life insurers, seven composite and seven Takaful. Input variables taken are management expenses, labor costs and Invested assets as input variables and gross income and investment income are out put variables using Data Envelopment Analysis. Findings revealed that insurance companies have a higher technical efficiency than their Takaful counterparts. 
2.3 Previous work

\begin{tabular}{|c|c|c|c|c|}
\hline Study & $\begin{array}{l}\text { Input } \\
\text { Variables }\end{array}$ & $\begin{array}{l}\text { Output } \\
\text { Variables }\end{array}$ & Tool & Result \\
\hline $\begin{array}{l}\text { Efficiency } \\
\text { Measure of } \\
\text { Insurance v/s } \\
\text { Takaful by Khan } \\
\text { \& Noreen (2014) }\end{array}$ & $\begin{array}{l}\text { Labor cost, } \\
\text { Total fixed } \\
\text { assets, } \\
\text { Business } \\
\text { Services } \\
\text { and equity } \\
\text { capital }\end{array}$ & $\begin{array}{l}\text { Premium } \\
\text { income }\end{array}$ & $\begin{array}{l}\text { DEA } \\
\text { mode } \\
1\end{array}$ & $\begin{array}{l}\text { Insurance companies } \\
\text { are less efficient than } \\
\text { Takaful counterparts } \\
\text { due to high allocative } \\
\text { efficiency leads to the } \\
\text { conclusion that their } \\
\text { choice of inputs is not } \\
\text { optimal. }\end{array}$ \\
\hline $\begin{array}{l}\text { Organizational } \\
\text { Form And } \\
\text { Efficiency: The } \\
\text { Coexistence Of } \\
\text { Family } \\
\text { Takaful and Life } \\
\text { Insurance In } \\
\text { Malaysia } \\
\text { (Ismail, Alhabshi } \\
\text { \& Bacha, 2011). }\end{array}$ & $\begin{array}{l}\text { Management } \\
\text { expenses, } \\
\text { labor costs } \\
\text { and } \\
\text { Invested } \\
\text { assets }\end{array}$ & $\begin{array}{l}\text { gross } \\
\text { income } \\
\text { and } \\
\text { Investm } \\
\text { ent } \\
\text { income }\end{array}$ & $\begin{array}{l}\text { DEA } \\
\text { Excel } \\
\text { Solve } \\
r\end{array}$ & $\begin{array}{l}\text { Insurance companies } \\
\text { have higher technical } \\
\text { efficiency and scale } \\
\text { efficiency } \\
\text { compared to Takaful } \\
\text { companies. }\end{array}$ \\
\hline $\begin{array}{l}\text { An Analysis On } \\
\text { The Efficiency Of } \\
\text { Takaful } \\
\text { And Insurance } \\
\text { Companies In } \\
\text { Malaysia: A } \\
\text { Non-Parametric } \\
\text { Approach (Saad, } \\
\text { 2012). }\end{array}$ & $\begin{array}{l}\text { management } \\
\text { and } \\
\text { commission } \\
\text { expenses }\end{array}$ & $\begin{array}{l}\text { premium } \\
\text { and net } \\
\text { investm } \\
\text { ent } \\
\text { income }\end{array}$ & $\begin{array}{l}\text { DEA } \\
\text { Coelli } \\
\text { 's } \\
\text { Versi } \\
\text { on }\end{array}$ & $\begin{array}{l}\text { Overall, efficiency of } \\
\text { the Takaful } \\
\text { companies is found to } \\
\text { be below than their } \\
\text { conventional } \\
\text { counterparts. }\end{array}$ \\
\hline
\end{tabular}

Source: Developed by authors

Insurance and Takaful companies can be considered as units of production because they have proper inputs, processes and outputs. Their inputs include premium income, invested assets, employees like marketers and underwriters. The technology and procedures process these inputs and generate profit or loss for the shareholders and claim amounts for their covered customers. Cummins 
and Weiss (1999) considered insurance companies as production units while comparing the efficiency of US stock and mutual insurance companies.

In the study by Khan and Noreen (2014), the list of companies taken as sample shows that most of the insurance companies were established before 1980's while Takaful companies are established after 2006 which may have an impact on results. Moreover, the sample contains a mix of general and life insurance and Takaful companies. As mentioned earlier, general insurance and Takaful companies provide financial compensation when defined loss occurs to covered vehicles, buildings, physical stock, and machinery etc while life insurance and Takaful companies provide compensation when death or disability of the customer occurs. They both have different structures and varying break -even points. Life insurance Company's break - even point is around six to ten years while general insurance companies have around five years (Business today, 2017). Same is the case with general and family Takaful companies. Year of establishment also has an impact on the performance of the companies, as the older companies normally have a large size in terms of number of customers, premium and geographical spread which also affects their premium income and claims figures.

Therefore, in this study, the sample consists of three general insurance and three general Takaful companies with year of establishments close to each other so that the results may remain more relevant and comparable.

Following are the details of insurance and takaful companies considered in Khan and Noreen (2014)'s study showing years of establishment and their type; either being a general (non - life) company or life.

\begin{tabular}{|l|l|l|l|}
\hline S.No & Insurance Company & $\begin{array}{l}\text { Year of } \\
\text { Establishment } \\
\text { (Taken from } \\
\text { company's } \\
\text { websites) }\end{array}$ & General/ Life \\
\hline 1 & Adamjee Insurance & $\begin{array}{l}\text { Adamjee } \\
\text { General: } 1960 \\
\text { Adamjee Life: } \\
2008\end{array}$ & $\begin{array}{l}\text { Not mentioned } \\
\text { whether they are } \\
\text { considering Adamjee } \\
\text { general or life. Not } \\
\text { mentioned in appendix } \\
\text { B }\end{array}$ \\
\hline 2 & Askari General & 1995 & General \\
\hline
\end{tabular}


Malik et al.

\begin{tabular}{|c|c|c|c|}
\hline 3 & $\begin{array}{l}\text { Atlas General Insurance } \\
\text { Company }\end{array}$ & 1934 & \\
\hline 4 & Premier Insurance & 1952 & General \\
\hline 5 & Shaheen Insurance & 1996 & General \\
\hline 6 & EFU - General & 1932 & \\
\hline 7 & EFU Life & 1992 & \\
\hline 8 & $\begin{array}{l}\text { State life Insurance } \\
\text { Corporation of Pakistan }\end{array}$ & 1972 & \\
\hline 9 & $\begin{array}{l}\text { National Insurance } \\
\text { Company Limited }\end{array}$ & 2000 & General \\
\hline 10 & New Jubilee insurance & $\begin{array}{l}\text { Jubilee Life } \\
1995 \\
\text { Jubilee General } \\
1953\end{array}$ & $\begin{array}{l}\text { Study doesn't mention } \\
\text { whether they are } \\
\text { taking Jubilee general } \\
\text { or life in their data }\end{array}$ \\
\hline 11 & Habib Insurance & 1942 & General \\
\hline
\end{tabular}

Takaful Companies

\begin{tabular}{|l|l|l|l|}
\hline S.No & Takaful Company & $\begin{array}{l}\text { Year of } \\
\text { Establishment }\end{array}$ & General/ Life \\
\hline 1 & Pak Kuwait Takaful Company & 2006 & General \\
\hline 2 & Takaful Pakistan Limited & 2007 & General \\
\hline 3 & Pak Qatar General Takaful & 2008 & General \\
\hline 4 & $\begin{array}{l}\text { Pak Qatar Family Takaful } \\
\text { Company }\end{array}$ & 2008 & Life \\
\hline 5 & $\begin{array}{l}\text { Dawood Family Takaful } \\
\text { Company }\end{array}$ & 2007 & Life \\
\hline
\end{tabular}


Among insurance companies, only two are life insurance while remaining 09 are general insurance companies. Among takaful, one company is life while 04 are general takaful companies. Regarding year of establishment, 06 insurance companies are established in or before 1960, one company in 1972 while the rest are in or before 2000 while all takaful companies are established after 2005. Older companies normally have a large set up resulting in economies of scale, thus improving their efficiencies. Comparing them with new companies may not be appropriate. Therefore, in this study, only general insurance and takaful companies are taken and insurance companies are selected with due care with year of establishment close to 2000. Following details can be checked:

Companies Selected in the Current Study:

\begin{tabular}{|l|l|l|l|}
\hline S.No & $\begin{array}{l}\text { Insurance } \\
\text { Company }\end{array}$ & $\begin{array}{l}\text { Year of } \\
\text { Establishment }\end{array}$ & General/ Life \\
\hline 1 & $\begin{array}{l}\text { Al Falah } \\
\text { Insurance }\end{array}$ & 2006 & General \\
\hline 2 & $\begin{array}{l}\text { PICIC } \\
\text { Insurance }\end{array}$ & 2004 & General \\
\hline 3 & $\begin{array}{l}\text { Asia } \\
\text { Insurance }\end{array}$ & 2008 & General \\
\hline
\end{tabular}

Takaful Companies

\begin{tabular}{|l|l|l|l|}
\hline S.No & $\begin{array}{l}\text { Takaful } \\
\text { Companies }\end{array}$ & $\begin{array}{l}\text { Year of } \\
\text { Establishment }\end{array}$ & General/ Life \\
\hline 1 & $\begin{array}{l}\text { Pak Kuwait } \\
\text { Takaful }\end{array}$ & 2006 & General \\
\hline 2 & Takaful Pakistan & 2007 & General \\
\hline 3 & Pak Qatar General & 2008 & General \\
\hline
\end{tabular}

Based on close year of establishment of insurance and takaful companies and being all general companies, results are comparable.

Moreover, the current study also makes a methodological contribution by using following financial ratings of the companies for the period under consideration 
while analysing the results. The use of financial ratings is not found in the previous studies in the analysis.

Table 2.1 Financial rating of insurance and Takaful companies carried out by JCR-VIZ and PACRA rating agencies operating in Pakistan for the period under consideration.

\begin{tabular}{|l|c|c|c|c|c|}
\hline Company & 2011 & 2012 & 2013 & 2014 & 2015 \\
\hline Al Falah Insurance (AF) & $\mathrm{A}^{-}$ & $\mathrm{A}$ & $\mathrm{A}$ & $\mathrm{A}+$ & $\mathrm{AA}^{-}$ \\
\hline PICIC Insurance (PICIC) & $\mathrm{A}^{-}$ & $\mathrm{BBB}+$ & $\mathrm{BBB}+$ & $\mathrm{BBB}+$ & $\mathrm{BBB}+$ \\
\hline Asia care Insurance(AS) & $\mathrm{BBB}+$ & $\mathrm{A}^{-}$ & $\mathrm{A}^{-}$ & $\mathrm{A}^{-}$ & $\mathrm{A}^{-}$ \\
\hline Takaful Pakistan (TP) & $\mathrm{BBB}+$ & $\mathrm{BBB}+$ & $\mathrm{BBB}+$ & $\mathrm{BBB}+$ & $\mathrm{BBB}+$ \\
\hline $\begin{array}{l}\text { Pak Qatar General } \\
\text { Takaful (PQ) }\end{array}$ & $\mathrm{BBB}+$ & $\mathrm{BBB}+$ & $\mathrm{A}-$ & $\mathrm{A}-$ & $\mathrm{A}-$ \\
\hline Pak Kuwait Takaful & $\mathrm{A}-$ & $\mathrm{A}-$ & $\mathrm{A}-$ & & $\mathrm{BBB}$ \\
\hline
\end{tabular}

\section{Theoretical Framework, Methodology and Data}

\subsection{Theoretical Framework of the study}

Figure 3.1 Theoretical Framework

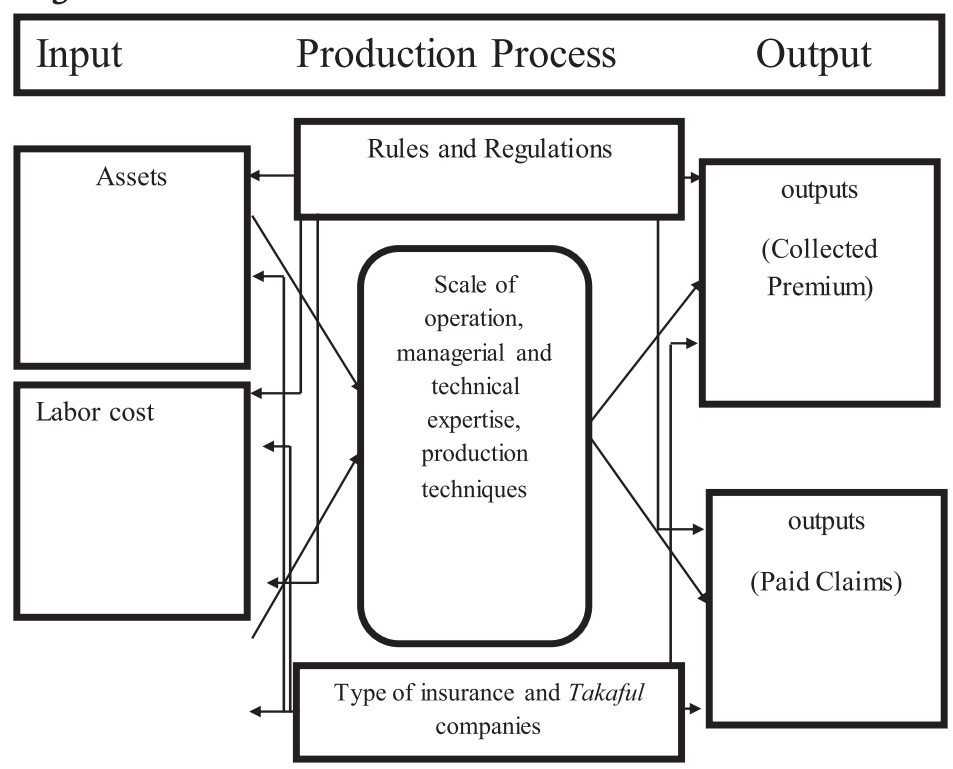

Source: (Khan \& Sulaiman, 2016). 
We shall consider labor cost and assets as input variables while premium and paid claims as out-put variables.

\section{Input}

Input factors are those which produce/generate a product or service. Quality of output greatly depends on the input factors. In this study, input variables are labor cost and assets.

\section{Processes}

It's the system, technology, procedures, rules and regulations which converts the input elements into output. For a manufacturing concern, it's the machinery and procedures that convert the raw material into output. For insurance and takaful companies, the procedures of underwriting, customer service etc. can be considered as their processes. Underwriting is the process in which a company decides about the request of a client asking for insurance either to give the coverage or to reject and if it decides to give the coverage, then what should be the rate of premium or contribution.

\section{Output}

It may be in the form of a physical product or service. Its quality greatly depends on the quality of input factors and the processes. In this study, out - put variables are premium and net paid claims. Premium is the price of insurance coverage provided by the company. The coverage commences when the client pays the premium. A specific amount is claimed by the client if the covered loss occurs and is paid by the company to the client or legal heirs.

Insurance and takaful companies invest their assets and employ staff for ensuring profit for their shareholders and quality service to their clients. With these assets and staff, companies generate premium and pay claims to their customers. In this study, we try to check how efficiently companies are using their assets and staff for generating premium and paying claims.

\subsection{Methodology}

Merriam-Webster Dictionary defines efficiency as effective operation as measured by a comparison of production with cost (as in energy, time, and money)". It is linked with one of the utility concepts of economics. Being commercial financial institutions, both insurance and Takaful companies are concerned with earning more profit with less resource, thus remaining more and more efficient. Previously, ratio analysis has remained in use for measuring efficiency while in the last few decades; use of frontier methodologies has started. This method gives very meaningful and relevant results. Frontier 
methodology has parametric and non - parametric approaches namely Stochastic Frontier Analysis, Thick Frontier Analysis and non-parametric techniques like Data Envelopment Analysis (Khan \& Noreen, 2014). Researchers mainly use DEA method for measuring efficiency of insurance companies, as it can handle several input and output variables (Saad, 2012).

Comparison of general insurance with general Takaful is selected because both of them focus coverage of an asset against the risk of loss due to a covered physical threat while life insurance and (family) Takaful companies focus on risk of loss due to death and disability of the covered clients. Due to the differences in services of general and life, their financial statements and data reporting also differ (Cummins \& Xie, 2013). Several studies have focused on measuring efficiency in insurance companies while few studies carried out in Malaysia have also measured it in Takaful companies. However, very little work has been carried out on Takaful companies operating in Pakistan therefore, we take five insurance and Takaful companies established nearly in same periods using non-parametric approach taking data from 2011 - 2015 by applying DEA. Efficiency scores are calculated using Efficiency Measurement System (EMS) 1.3. We take labor cost and assets as input variables and premium and paid claims as output variables.

Charnes et al., (1978) initially used data envelopment analysis in their study (Saad, 2012). Later on, Banker (1984) also utilized the same technique. This technique focuses on gauging the relative efficiency in firm with best practices. DEA has two parts: technical efficiency and allocative efficiency. Technical efficiency tells us the minimum inputs required for a specific output and maximum output for a specific input. Allocative efficiency tells us the proportion of optimal level of input for a given output. Technical efficiency can be further divided into pure technical efficiency and scale efficiency. Pure technical efficiency occurs when firm maximizes output with variable return to scale and scale efficiency occurs when firm operates at constant return to scale (Khan \& Noreen, 2014).

The Mathematical form of the DEA model could be explained in the following. In the DEA, we calculate score for each DMU based on output-input ratio by giving specific weight.

Score $=$ Output $/$ Input $(s)$

We give specific weight to each input and the resulting output.

Score $=$ Weighted Output $/$ Weighted Input(s). 
A DMU is said to be efficient if the total score is equal to one, while, by receiving a score having less than one, the DMU would be relative inefficient.

The DEA analysis is based on linear programming.

Let us consider that there are six numbers of DMUs varying from 1 up to 6 and the Vector of DMUs is denoted by $D_{i}$ :

$D_{1}, D_{2}, D_{3}, D_{4}, D_{5}, D_{6}$

The vector of Inputs is given by $I T$;

$I t_{1}, I t_{2}$

The output vector denoted byOT;

$O t_{1}, O t_{2}$

\section{The input-oriented efficiency for $i^{\text {th }} D M U$}

In input-oriented efficiency, our objective is to achieve the fixed level of output by utilizing the possible minimum level of inputs.

$\operatorname{Min} \emptyset$ (iv)

Constrain Function $\left\{\begin{array}{l}\rho I t_{i} \leq \emptyset I T \\ \rho O t_{i} \geq O T \\ \sum_{i=1}^{n} \rho_{i}=1 \\ \rho_{i} \geq 0\end{array} \emptyset \ldots \ldots . . . . .\right.$.

In equation (iv) and (v), Øis the efficiency score measuring the technical efficiency of $\mathrm{i}$-th DMU. The value of $\emptyset$ is less than or equal to $1(\emptyset \leq 1)$.A DMU is said to be inefficient and lies inside the frontier if the value of $\emptyset$ is less than one. Alternatively, a DMU is said to be efficient if the value of $\emptyset$ is equal to one and hence the DMU will lie on production frontier curve. $\rho$ is the measure of weight given to $\mathrm{i}$-th DMU and gives location to $\mathrm{i}$-th DMU according to its efficiency.

This study also makes a methodological contribution by using financial ratings of the companies for the period under consideration while analysing the results. The use of financial ratings is not found in the previous studies. It helps in linking and justifying the results with the year wise financial performance of the companies.

\subsection{Data and Variables}

In the study, insurance and Takaful companies are considered decision making units (DMU's) which gives output including premium and net claims with inputs of assets and labor. Variables are displayed in the following table. 
Table 3. 1: List of Inputs \& Outputs

\begin{tabular}{|l|lll|}
\hline Input/output & Variable & Description & Unit \\
\hline Input & Assets & $\begin{array}{l}\text { Total assets of a company } \\
\text { invested in Pak Rupees }\end{array}$ & $\begin{array}{l}\text { Pak Rs. In } \\
\text { millions }\end{array}$ \\
Input & $\begin{array}{l}\text { Labor } \\
\text { Cost }\end{array}$ & $\begin{array}{l}\text { Cost of labor employed in the } \\
\text { company per annum. }\end{array}$ & Pak Rs. In \\
& Premium & $\begin{array}{l}\text { Total premium collected by } \\
\text { the company in a year }\end{array}$ & $\begin{array}{l}\text { Pak Rs. In } \\
\text { millions }\end{array}$ \\
Output & $\begin{array}{l}\text { Net } \\
\text { Claims }\end{array}$ & $\begin{array}{l}\text { Total amount of claims paid } \\
\text { by the company in a year }\end{array}$ & $\begin{array}{l}\text { Pak Rs. In } \\
\text { millions }\end{array}$ \\
\hline
\end{tabular}

Source: Developed by author

The data is collected from the declared financial statements of the companies displayed at their websites. The study uses panel data for six selected insurance and Takaful companies of Pakistan from the year 2011 to 2015. These companies include three insurance companies namely Al Falah, PICIC and Asia care. Three Takaful companies include Takaful Pakistan, Pak Qatar and Pak Kuwait. All of these companies are general companies i.e. all of them provide general (non - life) coverages like vehicles, buildings, machinery, physical stock etc. One of the reasons of their selection is their year of establishment is close to one another and all of these companies transact general insurance or Takaful business.

\section{Results}

Here, we will have a discussion on results of constant return to scale (CRS), variable return to scale (VRS), super efficiency with respect to CRS and VRS, scale efficiency, returns to scale worked out through using data envelopment analysis. Results are displayed in the Table $-4.1,4,2$

Table 4.1: Overall Technical Efficiency (Constant Return to Scale), Pure Technical Efficiency in \% (VRS)

\begin{tabular}{|c|c|c|c|c|c|c|c|c|c|c|}
\hline \multirow[t]{2}{*}{$\begin{array}{l}\text { Efficiency } \\
\text { in } \%\end{array}$} & \multicolumn{5}{|c|}{$\begin{array}{l}\text { Overall Technical } \\
\text { Efficiency (CRS) }\end{array}$} & \multicolumn{5}{|c|}{$\begin{array}{l}\text { Pure Technical } \\
\text { Efficiency (VRS) }\end{array}$} \\
\hline & 2011 & 2012 & 2013 & 2014 & 2015 Mean & 2011 & 2012 & 2013 & 2014 & 2015 Mean \\
\hline Alfalah & 100 & 100 & 100 & 100 & 100 & 100 & 100 & 100 & 100 & 100 \\
\hline PICIC & 100 & 90 & 67 & 77 & 84 & 100 & 91 & 81 & 78 & 100 \\
\hline Asia & 45 & 54 & 68 & 100 & 100 & 100 & 100 & 100 & 100 & 100 \\
\hline
\end{tabular}


COMSATS Journal of Islamic Finance

\begin{tabular}{|l|cccccc|cccccc|}
\hline Mean & $\mathbf{8 1}$ & $\mathbf{8 1}$ & $\mathbf{7 8}$ & $\mathbf{9 2}$ & $\mathbf{9 4}$ & $\mathbf{8 5}$ & $\mathbf{1 0 0}$ & $\mathbf{9 7}$ & $\mathbf{9 3}$ & $\mathbf{9 2}$ & $\mathbf{1 0 0}$ & $\mathbf{9 6}$ \\
TPL & 100 & 100 & 69 & 58 & 72 & & 100 & 100 & 100 & 100 & 100 & \\
PQ & 51 & 100 & 100 & 100 & 100 & & 51 & 100 & 100 & 100 & 100 & \\
PK & 80 & 100 & 71 & 24 & 75 & & 94 & 100 & 88 & 25 & 25 & \\
Mean & 77 & $\mathbf{1 0 0}$ & $\mathbf{8 0}$ & $\mathbf{6 0}$ & $\mathbf{8 2}$ & $\mathbf{7 9}$ & $\mathbf{8 1}$ & $\mathbf{1 0 0}$ & $\mathbf{9 6}$ & $\mathbf{7 5}$ & $\mathbf{7 5}$ & $\mathbf{8 5}$ \\
\hline
\end{tabular}

\subsection{Overall Technical Efficiency (CRS)}

Table 4.1 shows that in year 2011, Alfalah, PICIC and Takaful Pakistan Limited (TPL) overall efficiency (Constant return to scale -CRS) is $100 \%$ while that of Asia, Pak Qatar General Takaful (PQ) and Pak Kuwait Takaful (PK) is $45 \%, 51 \%$ $\& 81 \%$ respectively. Mean of overall efficiency of three insurance companies is $81 \%$ while mean of overall efficiency of Takaful companies in year 2011 is $77 \%$.

In year 2012, overall efficiency (Constant return to scale - CRS) of Alfalah insurance is $100 \%$, PICIC $90 \%$ and Asia is $54 \%$. In the same year, TPL, PQ and PK have their CRS equal to $100 \%$. Mean of overall efficiency of three insurance companies is $81 \%$ while mean of overall efficiency of Takaful companies is $100 \%$.

In year 2013, overall efficiency (Constant return to scale - CRS) of Alfalah insurance is $100 \%$, PICIC $67 \%$ and Asia is $68 \%$. In the same year, CRS of TPL is $69 \%, \mathrm{PQ} 100 \%$ and $\mathrm{PK}$ is $71 \%$. Mean of overall efficiency of three insurance companies is $78 \%$ while mean of overall efficiency of Takaful companies is $80 \%$. In year 2014, overall efficiency (Constant return to scale - CRS) of Alfalah insurance is $100 \%$, PICIC $77 \%$ and Asia is $100 \%$. In the same year, CRS of TPL is $58 \%, \mathrm{PQ} 100 \%$ and $\mathrm{PK}$ is $24 \%$. Mean of overall efficiency of three insurance companies is $92 \%$ while mean of overall efficiency of Takaful companies is $60 \%$.

In year 2015, overall efficiency (Constant return to scale - CRS) of Alfalah insurance is $100 \%$, PICIC $84 \%$ and Asia is $100 \%$. In the same year, CRS of TPL is $72 \%$, PQ $100 \%$ and PK is $75 \%$. Mean of overall efficiency of three insurance companies is $94 \%$ while mean of overall efficiency of Takaful companies is $82 \%$. Mean of overall efficiency of three insurance companies for the period 2011 2015 is $85 \%$ while mean of overall efficiency of Takaful companies for the period $2011-2015$ is $79 \%$.

\subsection{Pure Technical Efficiency (VRS)}

Table 4.1 shows that in year 2011, Alfalah, PICIC, Asia and Takaful Pakistan Limited (TPL) have pure technical efficiencies (Variable return to scale -VRS) equal to $100 \%$ while that of Pak Qatar (PQ) and Pak Kuwait Takaful (PK) have $51 \% \& 94 \%$ respectively. Mean of pure technical efficiencies of three insurance companies is $100 \%$ while mean of pure technical efficiency of Takaful companies in year 2011 is $81 \%$. 
In year 2012, all insurance and Takaful companies have pure technical efficiency equal to $100 \%$ with the exception of PICIC which has it equal to $91 \%$. Mean of pure technical efficiency of three insurance companies is $97 \%$ while mean of pure technical efficiency of Takaful companies is $100 \%$.

In year 2013, Alfalah, Asia, Takaful Pakistan and Pak Qatar have their pure technical efficiencies equal to $100 \%$ while PICIC and Pak Kuwait have it equal to $81 \%$ \& $88 \%$ respectively. Mean of pure technical efficiency of three insurance companies is $97 \%$ while mean of pure technical efficiency of Takaful companies is $100 \%$.

In year 2014, Alfalah, Takaful Pakistan and Pak Qatar have their pure technical efficiencies equal to $100 \%$ while PICIC, Asia \& Pak Kuwait have it equal to $78 \%$ $\& 25 \%$ respectively. Mean of pure technical efficiency of three insurance companies is $92 \%$ while mean of pure technical efficiency of Takaful companies is $75 \%$.

In year 2015, all insurance and Takaful companies have their pure technical efficiency equal to $100 \%$ with the exception of Pak Kuwait which has it equal to $25 \%$. Mean of pure technical efficiency of three insurance companies is $100 \%$ while mean of pure technical efficiency of Takaful companies is $75 \%$.

Mean of pure technical efficiency of three insurance companies for the period $2011-2015$ is $96 \%$ while mean of pure technical efficiency of Takaful companies for the period $2011-2015$ is $85 \%$.

Table 4.2: Super Efficiency under CRS, Super Efficiency under VRS

\begin{tabular}{|c|c|c|c|c|c|c|c|c|c|c|c|}
\hline Efficiency & \multicolumn{6}{|c|}{ Super Efficiency under CRS } & \multicolumn{5}{|c|}{ Super Efficiency under VRS } \\
\hline DMUs & 2011 & 2012 & 2013 & 2014 & 2015 & Mean & 2011 & 2012 & 2013 & 2014 & 2015 Mean \\
\hline Alfalah & 253 & 200 & 203 & 107 & 137 & & big & big & big & big & big \\
\hline PICIC & 119 & 90 & 67 & 77 & 84 & & 121 & 91 & 81 & 78 & 139 \\
\hline Asia & 45 & 54 & 68 & 158 & 164 & & 234 & 219 & 456 & 318 & 167 \\
\hline Mean & 139 & 114 & 112 & 114 & 128 & 121 & & & & & \\
\hline TPL & 152 & 101 & 69 & 58 & 72 & & 247 & 268 & 280 & 212 & 156 \\
\hline$P Q$ & 51 & 107 & 286 & 199 & 203 & & 51 & 107 & big & big & 203 \\
\hline PK & 80 & 108 & 71 & 24 & 75 & & 94 & big & 88 & 24 & 99 \\
\hline Mean & 94 & 105 & 142 & 93 & 116 & 110 & & & & & \\
\hline
\end{tabular}

\subsection{Super Efficiency under CRS}

Table 4.2 shows super efficiencies under constant return to scale, of insurance and Takaful companies for the period 2011 to 2015 . 
In year 2011, super efficiency under CRS of Alfalah insurance is $253 \%$, PICIC $119 \%$, Asia $45 \%$. Super efficiency under CRS of Takaful Pakistan Limited (TPL) is $152 \%$, Pak Qatar (PQ) is $51 \%$ and Pak Kuwait Takaful (PK) is $94 \%$. Mean of super efficiency under CRS of three insurance companies is $139 \%$ while mean of super efficiency under CRS of Takaful companies in year 2011 is $94 \%$.

In year 2012, super efficiency under CRS of Alfalah insurance is $200 \%$, PICIC 90\%, Asia 54\%. Super efficiency under CRS of Takaful Pakistan Limited (TPL) is $101 \%$, Pak Qatar (PQ) is $107 \%$ and Pak Kuwait Takaful (PK) is $108 \%$. Mean of super efficiency under CRS of three insurance companies is $114 \%$ while mean of super efficiency under CRS of Takaful companies in year 2011 is $105 \%$.

In year 2013, super efficiency under CRS of Alfalah insurance is 203\%, PICIC $67 \%$, Asia 68\%. Super efficiency under CRS of Takaful Pakistan Limited (TPL) is 69\%, Pak Qatar (PQ) is $286 \%$ and Pak Kuwait Takaful (PK) is $71 \%$. Mean of super efficiency under CRS of three insurance companies is $112 \%$ while mean of super efficiency under CRS of Takaful companies in year 2011 is $142 \%$.

In year 2014, super efficiency under CRS of Alfalah insurance is $107 \%$, PICIC $77 \%$, Asia $158 \%$. Super efficiency under CRS of Takaful Pakistan Limited (TPL) is $58 \%$, Pak Qatar (PQ) is $199 \%$ and Pak Kuwait Takaful (PK) is $24 \%$. Mean of super efficiency under CRS of three insurance companies is $114 \%$ while mean of super efficiency under CRS of Takaful companies in year 2011 is $93 \%$.

In year 2015, super efficiency under CRS of Alfalah insurance is $137 \%$, PICIC, 84\%, Asia $164 \%$. Super efficiency under CRS of Takaful Pakistan Limited (TPL) is $72 \%$, Pak Qatar (PQ) is $203 \%$ and Pak Kuwait Takaful (PK) is $75 \%$. Mean of super efficiency under CRS of three insurance companies is $128 \%$ while mean of super efficiency under CRS of Takaful companies in year 2011 is $116 \%$.

Mean of super efficiency of three insurance companies for the period 2011 2015 is $121 \%$ while mean of pure technical efficiency of Takaful companies for the period $2011-2015$ is $110 \%$.

\subsection{Super Efficiency under VRS}

Table 4.2 shows super efficiencies under constant return to scale, of insurance and Takaful companies for the period 2011 to 2015.

In year 2011, super efficiency under CRS of Alfalah insurance is $253 \%$, PICIC $119 \%$ and Asia is $45 \%$. Super efficiency under CRS of Takaful Pakistan Limited (TPL) is $152 \%$, Pak Qatar (PQ) is $51 \%$ and Pak Kuwait Takaful (PK) is $94 \%$. Mean of super efficiency under CRS of three insurance companies is $139 \%$ while mean of super efficiency under CRS of Takaful companies in year 2011 is $94 \%$.

In year 2012, super efficiency under CRS of Alfalah insurance is $200 \%$, PICIC $90 \%$, Asia $54 \%$. Super efficiency under CRS of Takaful Pakistan Limited (TPL) is $101 \%$, Pak Qatar (PQ) is $107 \%$ and Pak Kuwait Takaful (PK) is $108 \%$. Mean of 
super efficiency under CRS of three insurance companies is $114 \%$ while mean of super efficiency under CRS of Takaful companies in year 2011 is $105 \%$.

In year 2013, super efficiency under CRS of Alfalah insurance is $203 \%$, PICIC $67 \%$, Asia 68\%. Super efficiency under CRS of Takaful Pakistan Limited (TPL) is $69 \%$, Pak Qatar (PQ) is $286 \%$ and Pak Kuwait Takaful (PK) is $71 \%$. Mean of super efficiency under CRS of three insurance companies is $112 \%$ while mean of super efficiency under CRS of Takaful companies in year 2011 is $142 \%$.

In year 2014, super efficiency under CRS of Alfalah insurance is $107 \%$, PICIC $77 \%$, Asia 158\%. Super efficiency under CRS of Takaful Pakistan Limited (TPL) is $58 \%$, Pak Qatar (PQ) is $199 \%$ and Pak Kuwait Takaful (PK) is $24 \%$. Mean of super efficiency under CRS of three insurance companies is $114 \%$ while mean of super efficiency under CRS of Takaful companies in year 2011 is $93 \%$.

In year 2015, super efficiency under CRS of Alfalah insurance is $137 \%$, PICIC $84 \%$, Asia $164 \%$. Super efficiency under CRS of Takaful Pakistan Limited (TPL) is $72 \%$, Pak Qatar (PQ) is $203 \%$ and Pak Kuwait Takaful (PK) is $75 \%$. Mean of super efficiency under CRS of three insurance companies is $128 \%$ while mean of super efficiency under CRS of Takaful companies in year 2011 is $116 \%$.

Mean of super efficiency of three insurance companies for the period 2011 2015 is $121 \%$ while mean of pure technical efficiency of Takaful companies for the period $2011-2015$ is $110 \%$.

\section{Table 4.3: Scale Efficiency (CRS-VRS), Returns to Scale}

\begin{tabular}{|c|c|c|c|c|c|c|c|c|c|c|c|}
\hline Efficiency & & Scale & fficic & ncy & & & & Returi & $s$ to $S$ & ale & \\
\hline & 2011 & 2012 & 2013 & 201 & 201 & Mean & 2011 & 2012 & 201 & 201 & 2015 Mean \\
\hline & 100 & 100 & 100 & 100 & 100 & & $\mathrm{CO}$ & $\mathrm{CO}$ & $\mathrm{CO}$ & $\mathrm{CO}$ & $\mathrm{CO}$ \\
\hline Alfalah & & & & & & & $\mathrm{N}$ & $\mathrm{N}$ & $\mathrm{N}$ & $\mathrm{N}$ & $\mathrm{N}$ \\
\hline & 100 & 98 & 82 & 98 & 84 & & $\mathrm{CO}$ & INC & $\mathrm{CO}$ & $\mathrm{CO}$ & $\mathrm{CO}$ \\
\hline PICIC & & & & & & & $\mathrm{N}$ & & $\mathrm{N}$ & $\mathrm{N}$ & $\mathrm{N}$ \\
\hline & 45 & 54 & 68 & 100 & 100 & & $\mathrm{CO}$ & $\mathrm{CO}$ & $\mathrm{CO}$ & $\mathrm{CO}$ & $\mathrm{CO}$ \\
\hline Asia & & & & & & & $\mathrm{N}$ & $\mathrm{N}$ & $\mathrm{N}$ & $\mathrm{N}$ & $\mathrm{N}$ \\
\hline Mean & 82 & 84 & 83 & 93 & 94 & 87 & & & & & \\
\hline & 100 & 100 & 69 & 58 & 72 & & $\mathrm{CO}$ & $\mathrm{CO}$ & $\mathrm{CO}$ & $\mathrm{CO}$ & $\mathrm{CO}$ \\
\hline TPL & & & & & & & $\mathrm{N}$ & $\mathrm{N}$ & $\mathrm{N}$ & $\mathrm{N}$ & $\mathrm{N}$ \\
\hline & 99 & 100 & 100 & 100 & 100 & & $\mathrm{CO}$ & $\mathrm{CO}$ & $\mathrm{CO}$ & $\mathrm{CO}$ & $\mathrm{CO}$ \\
\hline $\mathrm{PQ}$ & & & & & & & $\mathrm{N}$ & $\mathrm{N}$ & $\mathrm{N}$ & $\mathrm{N}$ & $\mathrm{N}$ \\
\hline & 85 & 100 & 80 & 95 & 82 & & INC & $\mathrm{CO}$ & $\mathrm{CO}$ & $\mathrm{CO}$ & $\mathrm{CO}$ \\
\hline PK & & & & & & & & $\mathrm{N}$ & $\mathrm{N}$ & $\mathrm{N}$ & $\mathrm{N}$ \\
\hline Mean & 93 & 100 & 83 & 84 & 84 & 88 & & & & & \\
\hline
\end{tabular}




\subsection{Scale Efficiency}

Table 4.4 shows scale efficiencies of insurance and Takaful companies for the period 2011 to 2015 .

In year 2011, scale efficiencies (CRS-VRS) of Alfalah insurance, PICIC and Takaful Pakistan is $100 \%$ while Asia is $45 \%$, Pak Qatar (PQ) $99 \%$ and Pak Kuwait Takaful (PK) is $85 \%$. Mean of scale efficiencies of three insurance companies is $139 \%$ while mean of super efficiency under CRS of Takaful companies in year 2011 is $94 \%$.

In year 2012, scale efficiencies of Alfalah insurance, Takaful Pakistan Limited (TPL), Pak Qatar (PQ), and Pak Kuwait Takaful (PK) is $100 \%$ while PICIC \& Asia have $98 \%$ \& $54 \%$ respectively. Mean of scale efficiencies of three insurance companies is $84 \%$ while mean of scale efficiencies of Takaful companies in year 2012 is $100 \%$.

In year 2013, scale efficiencies of Alfalah insurance \& Pak Qatar (PQ) is $100 \%$ while PICIC has $82 \%$ \& Asia has $68 \%$. Takaful Pakistan Limited (TPL) and Pak Kuwait Takaful (PK) have $69 \%$ \& $80 \%$ respectively. Mean of scale efficiencies of three insurance companies and three Takaful companies is same $83 \%$.

In year 2014, scale efficiencies of Alfalah insurance, Asia \& Pak Qatar (PQ) is $100 \%$ while PICIC has 98\%, Takaful Pakistan Limited (TPL) 58\% and Pak Kuwait Takaful (PK) is $95 \%$. Mean of scale efficiencies of three insurance companies is 93\% while mean of scale efficiencies of Takaful companies in year 2012 is $84 \%$.

In year 2015, scale efficiencies of Alfalah insurance, Asia \& Pak Qatar (PQ) is $100 \%$ while PICIC has $84 \%$, Takaful Pakistan Limited (TPL) $72 \%$ and Pak Kuwait Takaful (PK) is $82 \%$. Mean of scale efficiencies of three insurance companies is $94 \%$ while mean of scale efficiencies of Takaful companies in year 2012 is $84 \%$. Mean of scale efficiencies of three insurance companies for the period 2011 2015 is $87 \%$ while mean of pure technical efficiency of Takaful companies for the period $2011-2015$ is $88 \%$.

\subsection{Financial rating of insurance and Takaful companies}

Table 4.4 shows financial rating of insurance \& Takaful companies for the period under consideration. 
Table 4.5: Financial rating of insurance and Takaful companies carried out by JCR-VIZ and PACRA rating agencies operating in Pakistan for the period under consideration

\begin{tabular}{|l|c|c|c|c|c|}
\hline Company & 2011 & 2012 & 2013 & 2014 & 2015 \\
\hline $\begin{array}{l}\text { Al Falah Insurance } \\
\text { (AF) }\end{array}$ & A- & A & A & A+ & AA- \\
\hline $\begin{array}{l}\text { PICIC Insurance } \\
\text { (PICIC) }\end{array}$ & A- & BBB+ & BBB+ & BBB+ & BBB+ \\
\hline $\begin{array}{l}\text { Asia care Insurance } \\
\text { (AS) }\end{array}$ & BBB+ & A- & A- & A- & A- \\
\hline $\begin{array}{l}\text { Takaful Pakistan } \\
\text { (TP) }\end{array}$ & BBB+ & BBB+ & BBB+ & BBB+ & BBB+ \\
\hline $\begin{array}{l}\text { Pak Qatar General } \\
\text { Takaful (PQ) }\end{array}$ & BBB+ & BBB+ & A- & A- & A- \\
\hline Pak Kuwait Takaful & A- & A- & A- & & BBB \\
\hline
\end{tabular}

The rating shows that Alfalah is constantly improving its rating which is in conformity with its efficiency scores. PICIC insurance's efficiency scores were high in 2011 but now lowering down with every increasing year and same is the case with its financial rating. Asia care starts with low efficiency scores and improves gradually and similar trend can be noted in its financial rating. Takaful Pakistan has average efficiency scores during the period and same is the case with its ratings. Efficiency scores of Pak Qatar improves year by year and similar progress can be noted in the improvement in its ratings. Pak Kuwait did well in the efficiency scores in 2011\& 2012 but onwards, its score is dropping while similar trend can be noted in its financial ratings.

\section{Malmquist Index (MI) of insurance and Takaful companies}

Input Oriented CRS Malmquist index (MI) gives us a comparison of two periods and shows us whether the productivity of the DMU has improved, deteriorated or remained static. MI over 01 means improvement, 1 means static and less than 01 means deterioration in performance in a later period compared with the earlier. Efficiency Change over 01 show that the firm has retained its performance but due to outward shift in frontier results in MI less than 01 which means that the industry production has improved while production of the specific DMU has not improved. 
Table 5.1: Comparing Malmquist Index (MI) of insurance and Takaful companies in periods from 2011 to 2013

\begin{tabular}{|l|l|l|l|}
\hline Inputs & Outputs & First period & Second period \\
\hline Labor Cost & $\begin{array}{l}\text { Premium } \\
\text { collected }\end{array}$ & 2011 & 2013 \\
\hline Assets & Total claims paid & - & - \\
\hline
\end{tabular}

\begin{tabular}{|l|l|l|l|l|}
\hline $\begin{array}{l}\text { DMU } \\
\text { No. }\end{array}$ & $\begin{array}{l}\text { DMUs in } \\
\text { Period2 }\end{array}$ & $\begin{array}{l}\text { Input-Oriented } \\
\text { CRS Malmquist Index }\end{array}$ & $\begin{array}{l}\text { Efficiency } \\
\text { Change }\end{array}$ & $\begin{array}{l}\text { Frontier } \\
\text { Shift }\end{array}$ \\
\hline 1 & $\begin{array}{l}\text { Al Falah } \\
\text { Insurance }\end{array}$ & 0.95302 & 1.00000 & 0.95302 \\
\hline 2 & $\begin{array}{l}\text { PICIC } \\
\text { Insurance }\end{array}$ & 1.02386 & 1.24313 & 0.82362 \\
\hline 3 & $\begin{array}{l}\text { Asia } \\
\text { Insurance }\end{array}$ & 1.46890 & 1.46364 & 1.00359 \\
\hline 4 & $\begin{array}{l}\text { Takaful } \\
\text { Pakistan }\end{array}$ & 1.39014 & 1.04976 & 1.32425 \\
\hline 5 & $\begin{array}{l}\text { Pak Qatar } \\
\text { General } \\
\text { Takaful }\end{array}$ & 0.99610 & 1.00000 & 0.99610 \\
\hline 6 & $\begin{array}{l}\text { Pak Kuwait } \\
\text { Takaful }\end{array}$ & 1.09139 & 1.04527 & 1.04412 \\
\hline
\end{tabular}

Table 5.2: Comparing Malmquist Index (MI) of insurance and Takaful companies in periods from 2013 to 2015

\begin{tabular}{|l|l|l|l|}
\hline Inputs & Outputs & First period & Second period \\
\hline Labor Cost & $\begin{array}{l}\text { Premium } \\
\text { collected }\end{array}$ & 2013 & 2015 \\
\hline Assets & Total claims paid & - & - \\
\hline
\end{tabular}


Malik et al.

\begin{tabular}{|l|l|l|l|l|}
\hline $\begin{array}{l}\text { DMU } \\
\text { No. }\end{array}$ & $\begin{array}{l}\text { DMUs in } \\
\text { Period2 }\end{array}$ & $\begin{array}{l}\text { Input- } \\
\text { Oriented } \\
\text { CRS } \\
\text { Malmquist } \\
\text { Index }\end{array}$ & $\begin{array}{l}\text { Efficiency } \\
\text { Change }\end{array}$ & Frontier Shift \\
\hline 1 & Alfalah Insurance & 1.04930 & 1.00000 & 1.04930 \\
\hline 2 & PICIC Insurance & 0.97669 & 0.80442 & 1.21415 \\
\hline 3 & Asia Insurance & 0.68078 & 0.68323 & 0.99642 \\
\hline 4 & Takaful Pakistan & 0.71935 & 0.95260 & 0.75515 \\
\hline 5 & $\begin{array}{l}\text { Pak Qatar } \\
\text { General Takaful }\end{array}$ & 1.00391 & 1.00000 & 1.00391 \\
\hline 6 & Pak Kuwait & 0.91626 & 0.95669 & 0.95774 \\
\hline & Takaful & & & \\
\hline
\end{tabular}

Table 5.3: Comparing Malmquist Index (MI) of the two periods from 2011-2013 \& 2013-15

\begin{tabular}{|l|l|l|l|}
\hline $\begin{array}{l}\text { DMU. } \\
\text { No. }\end{array}$ & DMUs & $\begin{array}{l}2011-2013 \\
\text { Malmquist index }\end{array}$ & $\begin{array}{l}2013-2015 \\
\text { Malmquist } \\
\text { index }\end{array}$ \\
\hline 1 & Alfalah Insurance & 0.95302 & 1.04930 \\
\hline 2 & PICIC Insurance & 1.02386 & 0.97669 \\
\hline 3 & Asia Insurance & 1.46890 & 0.68078 \\
\hline & Mean & $\mathbf{1 . 1 4 8}$ & $\mathbf{0 . 9 1}$ \\
\hline 4 & Takaful Pakistan & 1.39014 & 0.71935 \\
\hline 5 & $\begin{array}{l}\text { Pak Qatar General } \\
\text { Takaful }\end{array}$ & 0.99610 & 1.00391 \\
\hline 6 & $\begin{array}{l}\text { Pak Kuwait } \\
\text { Takaful }\end{array}$ & 1.09139 & 0.91626 \\
\hline & Mean & $\mathbf{1 . 1 5 9}$ & $\mathbf{0 . 8 8}$ \\
\hline
\end{tabular}


In table 5.1, MI of Alfalah is less than 01 while Efficiency Change is 01. The score shows that Alfalah has retained its performance from 2011 to 2013 while the industry production has increased and the DMU production is $05 \%$ less than the industry. Production of PICIC has been improved in 2013 as its Malmquist index is more than 01. Performance of Asia care has also been increased as its MI is over 01. Takaful Pakistan and Pak Kuwait also have MI more than 01 showing increase in their production in the mentioned period. Pak Qatar has retained its performance but due to an outward shift in the frontier, its MI is less than 01 showing that its increase in production is less than the remaining industry. Mean of MI of insurance companies is 1.148 while Takaful companies have it equal to 1.159 . The means show more increase in production of Takaful companies as compared to their insurance counterpart in the period.

In table 5.2, MI of Alfalah is more than 01 showing increase in productivity from 2013 to 2015. Rating of Alfalah insurance has also been improved from 2013 onwards. Due to better performance and also being part of a big financial group, it scored well in efficiency. Productivity of PICIC and Asia insurance has decreased as their MI is less than 01. Takaful Pakistan and Pak Kuwait also have MI less than 01 showing decrease in their productivity in the mentioned period. Rating of Pak Kuwait Takaful has also been decreased in 2014 onwards. Pak Kuwait investment company owns Pak Kuwait Takaful as well as Meezan bank in Pakistan. Meezan bank provided good support to its sister concern from 2006 but afterwards, new general Takaful companies also came in while performance of Pak Kuwait got deteriorated. Resultantly, Meezan bank also started giving its availing services of other Takaful companies instead of its sister concern. Takaful Pakistan had around 12 branches which were reduced to 03 branches later on. Decrease in MI of Takaful Pakistan may be due to reduction in its size. As mentioned earlier, Pak Kuwait was having solvency reporting issues in 2015 with the regulator and it was fined during this period, which may have resulted in low MI.

Pak Qatar has improved its productivity as its malmquist index is more than 01. Rating of Pak Qatar General has also been improved from 2013 onwards. Pak Qatar Takaful group has two companies namely Pak Qatar Family Takaful company and Pak Qatar general Takaful company. Pak Qatar family Takaful is the largest family Takaful company of Pakistan in terms of number of customers and premium collection. Pak Qatar has a vital role in diffusion of Takaful knowledge in the market. People have become aware about Takaful by the workers of Pak Qatar. They have managed to change the attitude of the people about Takaful resulting in opting for Takaful instead of insurance. Therefore, presently, Pak Qatar is the pioneer and the biggest provider of 
family Takaful services in Pakistan. Due to large size of Pak Qatar Family Takaful, its general company also takes its advantage. Mostly, they have joined offices. Some staff provides services to both companies. Clients also trust it more due to its brand name and size. Mean of MI of insurance companies is 0.91 while Takaful companies have it equal to 0.88. The means show that productivity of insurance and Takaful companies has reduced but insurance companies are still better than their Takaful counterpart in the period.

\section{Discussion}

Table 5.3 shows that Alfalah insurance is consistently efficient company with scale efficiency score 1 during 2011 - 2015 while its super efficiency is more than 1 in the given period. Alfalah insurance, part of Abu Dhabi business group, was established in 2006. Abu Dhabi group also owns Alfalah bank and several other businesses in Pakistan. Normally, a general insurance company gets a solid support from its sister concern bank as the bank takes insurance coverage of the mortgaged and pledged assets of its borrowers from its sister concern insurance company. Thus, a regular and considerable premium income starts from its inception. Otherwise, it is difficult for a new company to remain highly efficient in its initial years.

Established in 2005, PICIC insurance company scale efficiency was 1.0 in 2011 but its efficiency declined in the onward years, however; it improved in year 2015. It was also owned by a bank called Pakistan industrial credit and investment corporation (PICIC). PICIC bank was acquired by NIB bank in 2007 while the amalgamation of NIB in MCB bank is in process. Change of ownership of PICIC group may be one of the reasons in declining efficiency of PICIC insurance.

Asia care insurance company was established in 2009 with low scores in initial years but improved gradually. Established in 2007, Takaful Pakistan Limited score was better in 2011 and 2012 which got reduced in onward years but got recovered in year 2015.Pak Qatar General Takaful was established in 2008 with low scores in year 2011 and got increased in onward years. Pak Qatar Takaful group owns Pak Qatar family Takaful limited (PQFTL) and Pak Qatar general Takaful limited (PQGTL). PQFTL is the largest family Takaful company in Pakistan and its better performance may also be due to the support of its sister general company. It may be one of the reasons of high efficiency of PQGTL.

Established in 2006, part of Pak Kuwait investment company, Pak Kuwait Takaful has better efficiency scores in 2011 \& 2012 reducing in year 2013 and 2014 and recovering in year 2015. Pak Kuwait Investment Company owns Pak Kuwait Takaful company limited (PKGTL), the first Takaful company in Pakistan and Meezan bank limited, the largest Islamic bank and $7^{\text {th }}$ largest bank 
in Pakistan. In the initial years of establishment of PKGTL, Meezan bank used to take Takaful coverages of all of its clients from its sister concern company resulting in more contributions (Price of insurance is called premium while the amount paid by the client to takaful company is called contribution) and thus efficiency level was better in those years. Later on, other general Takaful companies were also established. Meezan bank might have used its services as well. One of the reasons in declining efficiency can be reduction in contribution (premium) receipt. Moreover, management of PKGTL has remained under close surveillance of the regular due to some irregularities and misreporting covering in the period of 2014. After investigations by the regulator, PKGTL was fined for Rs. 01 million after confirmation of the irregularities in figures of premium earned and claims (SECP $\mathcal{E}$ Dawn News, 2016). The declining efficiency of PKGTL can be better understood with these investigations and penalties.

While looking at the means of Overall Technical Efficiency under CRS, Pure Technical Efficiency under VRS and Super Efficiency under CRS, insurance companies are more efficient than Takaful companies established in almost same years with same size offering similar coverages to their clients. Only in scale efficiency, mean of the scores of Takaful companies is better than insurance companies.

Among Takaful companies, efficiency scores of Pak Qatar General Takaful remain very consistent; though it was the last general Takaful Company established in Pakistan. It may be due to effective presence of its sister concern family Takaful company. Normally, family Takaful companies have more clients in number and volume as compared to a general Takaful company. Every living member of the society can become a client of life insurance or family Takaful company while for becoming a client of general insurance or Takaful company, one should own some property like vehicle, machinery, stock or building etc. Comparatively, marketing staff of a family Takaful company is also more in number. They interact with more people, thus playing a vital role in the knowledge sharing of Takaful in the society. People become more aware about Takaful through these marketing people. So, taking life coverage from a family Takaful company, they may also prefer to take general Takaful coverage from their sister concern company resulting in more contribution (premium) for the company which positively affects the efficiency scores.

\section{Methodological Contribution}

This study also makes a methodological contribution by using financial ratings of the companies for the period under consideration while analysing the results. 
The use of financial ratings is not found in the previous studies. It helps in linking and justifying the results with the year wise financial performance of the companies.

\section{Conclusion}

There are various studies on measuring efficiencies of insurance companies while lesser studies focus efficiencies of Takaful companies. In this study, we have made a comparison of efficiencies of insurance and Takaful of almost same size, establishment period close to each other and all providing general insurance or Takaful services. The findings show that insurance companies are more efficient than Takaful companies, though the difference between their efficiencies is not very high. Financial rating of insurance and Takaful companies also supports the efficiency scores. Takaful companies can improve their efficiencies with increasing their branch network as it will bring down per unit cost and will increase per share earnings for the shareholders. Minimum paid up capital requirement for general takaful and insurance company is same with Rs. 450 Million (SECP, 2020) while takaful companies are not allowed to offer several products due to Shariah objections which also give an edge to insurance companies. The regulator may consider a lesser paid capital requirement for takaful companies which will improve their efficiency. It may attract more foreign investment in takaful companies which will have a positive impact on economy. Takaful companies should also develop more innovative products and better services through further research in Shariah as presently Takaful companies cannot offer several products being offered by insurance companies namely bonds (surety and performance bonds for the contractors) etc. As mentioned earlier, in Pakistan, Takaful was introduced in 2006 and in 2015, market share of Takaful reached to only 2\% (Hanif \& Iqbal, 2017) while insurance companies were not allowed to offer takaful products. Therefore, in 2014, regulator allowed conventional insurance companies to offer Takaful products through window operations. After this allowance, more than 15 general insurance companies have started their window takaful operations which will increase takaful branch network and market share. With this study, we expect that more of such work may be carried out in future in comparison of process of claims, underwriting and product development of insurance and Takaful companies. This study will also give an insight to the regulator for making laws that enable companies to remain efficient. 


\section{References}

Banker, R. D., Charnes, A., \& Cooper, W. W. (1984). Some models for estimating technical and scale inefficiencies in data envelopment analysis. Management science, 30(9), 1078-1092.

Barros, C. P., Caporale, G. M., \& Ibiwoye, A. (2008). A two-stage efficiency analysis of the insurance industry in Nigeria. Uxbridge, UK: Centre for Empirical Finance (CEF).

Billah, M. M. S. (2007). 24 Islamic banking and the growth of Takaful. Handbook of Islamic Banking, 401.

Borscheid, P., \& Haueter, N. V. (Eds.). (2012). World insurance: the evolution of a global risk network. Oxford University Press.

Brussels Journal, "Vatican Paper Supports Islamic Finance" dated $12^{\text {th }}$ March, 2009 retrieved on $10^{\text {th }}$ July, 2017 from www.brusselsjournal.com/node/3189

Business Today (2014, June 28). SUD Life expects to break even in 2014-2015. Retrieved November 06, 2017, from http://www.businesstoday.in/money/insurance/sud-life-expects-to-breakeven-in-2014-2015/story/207663.html

Coelli, T. J., Rao, D. S. P., O'Donnell, C. J., \& Battese, G. E. (2005). An introduction to efficiency and productivity analysis. Springer Science \& Business Media.

Cummins, J. D., \& Rubio-Misas, M. (2001). Deregulation, consolidation, and efficiency: evidence from the Spanish insurance industry.

Cummins, J. D., \& Xie, X. (2013). Efficiency, productivity, and scale economies in the US property-liability insurance industry. Journal of Productivity Analysis, 39(2), 141-164.

Cummins, J. D., Weiss, M. A., \& Zi, H. (1999). Organizational form and efficiency: The coexistence of stock and mutual property-liability insurers. Management Science, 45(9), 1254-1269.

Diacon, S. R., Starkey, K., \& O'Brien, C. (2002). Size and efficiency in European long-term insurance companies: An international comparison. The Geneva Papers on Risk and Insurance. Issues and Practice, 27(3), 444-466.

Farooq, S. U., Chaudhry, T. S., Alam, F. E., \& Ahmad, G. (2010). An analytical study of the potential of Takaful companies. European Journal of Economics, Finance and Administrative Sciences, 20, 54-75.

Fukuyama, H. (1997). Investigating productive efficiency and productivity changes of Japanese life insurance companies. Pacific-Basin Finance Journal, 5(4), 481-509. 
Georgescu-Roegen, N. (1972). Process analysis and the neoclassical theory of production. American Journal of Agricultural Economics, 54(2), 279-294.

Gonulal, S. O. (Ed.). (2012). Takaful and Mutual Insurance: Alternative Approaches to Managing Risks. World Bank Publications.

Hanif, M., \& Iqbal, A. M. (2017). An evaluation of Takaful insurance: case of Pakistan. Journal of Islamic Economics, Banking and Finance, 113(6218), 1-26.

Hindu Business line, General insurance business may "break even in 5 years" retrieved on $03^{\text {rd }}$ August, 2017 from http://www.thehindubusinessline.com/money-and-banking/generalinsurance-business-may-break-even-in-5-years

Hussain, D. (2014, May 22). Insurance firms allowed to launch Takaful. Dawn News. Retrieved November 06, 2017, from http://www.dawn.com/news/1107792

IAAP (2019). Insurance Association of Pakistan. Retrieved from http://www.iap.net.pk/download/IAP-YearBook-2018-19-new.pdf

Ismail, N., Alhabshi, S. O., \& Bacha, O. I. (2011). Cost efficiency and investment performance: mutual and stock form in Malaysian insurance industry. Working paper, International Centre for Education in Islamic Finance (INCEIF), Malaysia.

Khan, A., \& Noreen, U. (2014). Efficiency measure of insurance v/s Takaful Firms using DEA approach: a case of Pakistan. Journal of International Islamic University: Islamabad, Islamic Economic Studies, 22(1), 139-158.

Khan, Z., \& Sulaiman, J. (2016). Social and financial efficiency of microfinance institutions in Pakistan. The Pakistan Development Review. 54(4) 389-403.

Mace, P. (2013, June 24). When Was The First Life Insurance Policy Issued? 2016. Retrieved November 06, 2017, from http://www.insurancelibrary.com/life-insurance/when-was-the-first-lifeinsurance-policy-issued

Malik, A. and Ullah, K. (2016) Introduction to Takaful: Theory and Practice. Peshawar: Palgrave Macmillan. Accessible at https://www.palgrave.com/gp/book/9789813290150

Mark. S. Dorfman (1998). Introduction to risk and insurance. $6^{\text {th }}$ Edition (p.3). Prentice Hall, Inc.

Merriam Webster Dictionary, Definition of efficiency" retrieved on $17^{\text {th }}$ June, 2017 from twww.merriam-webster.com/dictionary/efficiency Milliman (2016). Pakistan: Growth and developments in insurance sector. 
Norma, Md. S. (2012). An analysis on the efficiency of Takaful and insurance companies in Malaysia: a non-parametric approach. Review of Integrative Business E Economics Research, 1(1), 33-56.

Outreville, J. F. (1990). The economic significance of insurance markets in developing countries. Journal of Risk and Insurance, 487-498.

Oxford Dictionary (n.d). Definition of insurance in English. retrieved on $15^{\text {th }}$ June, 2017 from en.oxforddictionaries.com/definition/insurance

Redzuan, H., Rahman, Z. A., \& Aidid, S. S. S. H. (2009). Economic determinants of family Takaful consumption: Evidence from Malaysia. International Review of Business Research Papers, 5(5), 193-211.

Retrieved from https://milliman-cdn.azureedge.net//media/milliman/importedfiles/uploadedfiles/insight/periodicals/asiaealert/pakistan-growth-developments-insurance.ashx

Ryan, J. (1994). Advantages of insurance futures. The Actuary (April), 20.

SECP (2020). Securities exchange commission of Pakistan. https://eservices.secp.gov.pk/eServices/

SECP. (n.d.). Documents on Pak Kuwait Takaful Company. Retrieved November 6, 2017, from https://www.secp.gov.pk/document/order-noidenfpktcl20164827-ms-pak-kuwait-Takaful-company-limited

The Express Tribune (2015, August 05). Solvency condition: Pak-Kuwait Takaful Company fined. Retrieved November 06, 2017, from https:/tribune.com.pk/story/932997/solvency-condition-pak-kuwaitTakaful-company-fined/

The Pakistan Credit Rating Agency Limited (November, 2011). Insurance Sector - 2011. Retrieved on $10^{\text {th }}$ June, 2017 from http://www.pacra.com.pk/pages/research/web_sector_study/insurance/Insu rance_study_Nov_11.pdf

Trenerry, C. F. (1926). The origin and early history of insurance: including the contract of bottomry. The Lawbook Exchange, Ltd.

Zainuddin, S., \& Noh, I. N. M. (2013). An overview of the emergence of Takaful: An Islamic type of insurance policy. International Journal of Business and Economics Research, 2(5), 112-115. 